\title{
Water uptake kinetics in soaking of grass pea
}

\author{
Rui COSTA ${ }^{1,2 *}$ (D), Verónica PEDROSO ${ }^{1}$, Tiago MADEIRA ${ }^{1}$ João GÂNDARA ${ }^{1}$
}

\begin{abstract}
Grass pea (Lathyrus sativus) is a pulse of great importance for food and feed due its high resistance to poor environmental conditions. However, it contains anti-nutritional factors and a neurotoxin, which is partially lost during soaking. A first approach to mass transfer during the soaking of grass pea was carried out by modeling the water uptake during soaking time using empirical mathematical models. The water uptake behavior was successfully described by the Peleg and the Exponential models, with these models showing several advantages when compared to the Mitscherlich and Page models. Both models estimated an increase of the equilibrium moisture content at temperatures between $50^{\circ} \mathrm{C}$ and $100^{\circ} \mathrm{C}$, and detected an increasing effect of the area per volume ratio of the seed on the water uptake rate, but only at $75{ }^{\circ} \mathrm{C}$ and $100{ }^{\circ} \mathrm{C}$. Additionally, grass pea presented a high true porosity, $13.651 \%$, showing that it contains a large empty volume into which water can enter by capillary flow. Solids loss was observed to be high, varying from $18 \%$ at $25^{\circ} \mathrm{C}$ to $44 \%$ at $100{ }^{\circ} \mathrm{C}$ for long soaking times, confirming that its effect in soaking cannot be neglected.
\end{abstract}

Keywords: Lathyrus sativus; soaking; kinetics; swelling; porosity.

Practical Application: Mathematical models to optimize water uptake and solids loss during soaking of grass pea.

\section{Introduction}

Grass pea (Lathyrus sativus L.) belongs to Leguminosae botanical family, also called Fabaceae or Papilionaceae (Yadav \& Bejiga, 2006). This family has three subfamilies, including Papilionoideae, to which the seed legumes belong. It represents the most economically important group of flowering plants in the human and animal diet (Doyle \& Luckow, 2003). From the 187 of the genus Lathyrus, grass pea is the only used as food and is of great economic importance in India, Bangladesh, Pakistan, Nepal and Ethiopia (Campbell, 1997). It is also grown in Central, South and Eastern Europe, West Asia and North Africa. It is a crop that withstands poor soil and extreme environmental conditions, such as drought and flooding. As a result, besides being an essential source of proteins in poor regions, it also has a potential of use in wealthier regions due to the worldwide trend of increasing consumption of vegetable proteins and climate change resulting in changing agricultural conditions. However, care should be taken on an exclusive dependence on grass pea for protein intake, which is undesirable due to the presence of the toxin $\beta$-ODAP that is active when a complement of sulphur containing amino acids is not supplied in the diet (Ngudi et al., 2012).

Grass pea is used in different ways, such as flour to make bread in India (Kenghe et al., 2013) or served boiled in Portugal. Soaking is the main grass pea processing operation carried out in a variety of conditions, from ambient temperature, usually for almost a day, to simultaneous cooking at temperatures up to $100^{\circ} \mathrm{C}$. Soaking has the advantage of leaching the antinutritional factors, that in the case of grass pea are trypsin inhibitors, phytic acid, tannins, and the undesirable neurotoxin $\beta$-ODAP (Hailu et al., 2015). Grass pea soaking may take place in water or in calcium hydroxide, tamarind, mixed salt (bicarbonate, soda, citric acid) or wood ash solutions (Urga et al., 2006; Yerra et al., 2015). When performed before cooking, soaking of grass pea also decreases cooking time and, consequently, energy consumption (Urga et al., 2006). As in other pulses, water uptake during soaking of seeds enables starch gelatinization during cooking at temperatures above $55^{\circ} \mathrm{C}$ (Turhan \& Sagol, 2004). These changes enable the softening of the seeds after which can be eaten.

To the authors knowledge, the kinetics of grass pea soaking have not been studied before and its mathematical modeling has not been attempted. This is essential to optimize soaking operation in terms of energy consumption, nutrient composition and waste minimization. The present work aims to study water transfer changes during soaking of grass pea with different seed size, at different temperatures, and relate it with macro observations of the inner seed, its true porosity, and solids loss.

\section{Materials and methods}

\subsection{Grass pea (Lathyrus sativus L.)}

Grass pea was obtained from a local producer of Alvaiázare (at the central region of Portugal), obtained from the same field during June. The seeds were kept at room temperature $\left(20-30^{\circ} \mathrm{C}\right)$ with relative humidity below $60 \%$ until October when the study 
was done. Due to the non-standard shape of the seed, in order to study the influence of size on the soaking kinetics, three size classes were considered, based on area per volume ratio (Table 1).

\subsection{Physical and chemical analyses}

\section{Volume}

The Boyle method (pycnometer method) was used to obtain the apparent volume of the grass pea (Sahin \& Sumnu, 2006). The solvent used was (anhydrous, $99.8 \%$, Sigma-Aldrich) in a $25 \mathrm{~mL}$ pycnometer.

\section{Surface area}

The surface area of the grass pea was measured by a weight method. Each seed was covered with a plastic film, the film piece weighed and converted into area using its known surface density.

\section{Water and solids contents}

Each grass pea was crushed and placed in a small pottery flask. The water and solids contents were determined by drying each seed at $105^{\circ} \mathrm{C}$, until constant weight.

\section{True porosity}

True porosity, defined as the ratio between the void volume inside a seed and the apparent volume of the seed (Sahin \& Sumnu, 2006), was determined by mercury porosimetry using Micrometrics' AutoPore IV 9500 (Norcross, USA). To account for the different possible porosities of different grass pea seed sizes, porosity was measured on a sample of 5 seeds with an average weight $0.5804 \mathrm{~g}$ and on a sample of 9 seeds with an average weight of $0.2768 \mathrm{~g}$.

\section{Seed coat-cotyledons interface observation}

Several raw grass pea seeds were cut open and observed with a stereo microscope (Leica EZ4D, Leica Microsystems, Germany) at 30x magnification to observe the separation between seed coat and cotyledons.

\subsection{Soaking kinetics}

Soaking kinetics results were obtained at two temperatures below gelatinization $\left(25^{\circ} \mathrm{C}\right.$ and $\left.50^{\circ} \mathrm{C}\right)$ and at two temperatures above gelatinization $\left(75^{\circ} \mathrm{C}\right.$ and $\left.100^{\circ} \mathrm{C}\right)$, in order to evaluate how gelatinization affects water transfer. At least 10 soaking times were tested to obtain water uptake curves until constant weight, with the maximum soaking time increasingly shorter for higher temperatures. Experimental data for each time-temperature was obtained from 5 replicates.

Table 1. Physical characterization of the grass pea seed groups.

\begin{tabular}{ccr}
\hline $\begin{array}{c}\text { Average mass of } \\
100 \text { seeds }(\mathrm{g})\end{array}$ & $\begin{array}{c}\text { Water content } \\
(\mathrm{m} / \mathrm{m} \%, \mathrm{wb})\end{array}$ & $\mathrm{A} / \mathrm{V}\left(\mathrm{cm}^{-1}\right)$ \\
\hline $0.2920( \pm 0.0589)$ & $11.86( \pm 0.55)$ & $11.47( \pm 1.97)$ \\
$0.4796( \pm 0.0679)$ & $13.85( \pm 0.33)$ & $9.86( \pm 1.63)$ \\
$0.7570( \pm 0.0805)$ & $14.07( \pm 0.78)$ & $8.71( \pm 0.48)$ \\
\hline
\end{tabular}

Each grass pea was weighed individually, immersed in $10 \mathrm{~mL}$ of water in a closed $25 \mathrm{~mL}$ Duran flask (Wertheim, Germany) and immersed during a chosen time in a thermal water bath (Precisterm Selecta, Barcelona). After reaching the chosen soaking time, the seed was drained to remove the excess of water, weighed again and the moisture content measured.

After each soaking time $t(\mathrm{~h})$, the total mass of the grass pea $(M, \in g)$ is the sum of the mass of water in the grass pea $\left(M_{w^{\prime}} \in g\right)$ and the mass of solids of the grass pea $\left(M_{\xi} \in g\right)$ (Equation 1):

$M=M_{w}+M_{s}$

The overall changes in the seed, mass and volume, were studied considering the ratios, of mass and volume (Equation 2):

$M^{n}=\frac{M}{M_{i}}$

where $M_{i}$ is the grass pea initial mass or volume $\left(\mathrm{g} \mathrm{or} \mathrm{cm}^{3}\right)$ and $M$ is the same property at time $t\left(\mathrm{~g}_{\mathrm{or}} \mathrm{cm}^{3}\right)$.

The water mass and the solids mass were normalized using the initial mass according to, respectively, Equations 3 and 4:

$X_{w}^{n}=\frac{M_{w}}{M_{i}} \times 100$

$X_{s}^{n}=\frac{M_{s}}{M_{i}} \times 100$

where $X_{w}^{n}$ is the ratio of water present in a grass pea seed per initial mass of the seed $(\%, \mathrm{~m} / \mathrm{m})$ and $X_{s}^{n}$ is the ratio of total solids present in a grass pea seed per initial mass of the seed $(\% \mathrm{~m} / \mathrm{m})$. This normalization decreases the variability of results due to differences in the grass pea initial mass, since a heavier grass pea, considering an equal density, will also have a larger area and volume and, consequently, will exchange more water and solids.

The equilibrium water content $X_{w, e}(\%, \mathrm{~m} / \mathrm{m}, \mathrm{db})$ was estimated as follows in Equation 5:

$X_{w, e}=\frac{X_{w, e}^{n}}{X_{s, e}^{n}} \times 100$

The temperature dependency of models' constants was described by an Arrhenius type equation (Equation 6):

$k=k_{0} e^{ \pm \frac{E a}{R T}}$

where $k$ is the constant, $E a(\mathrm{~kJ} / \mathrm{mol})$ the activation energy, $R$ is the gas constant $(8.314 \mathrm{~J} / \mathrm{mol} \mathrm{K})$ and $T(\mathrm{~K})$ the absolute temperature.

\subsection{Mathematical models}

Grass pea has a non-ideal shape, i.e., it is not a sphere like, a cylinder, a plate or a semi-infinite solid, neither can be derived from these. For mass transfer modeling, its shape can be approximated to one resulting from the intersection of these 
ideal shapes. Because of this as a first approach to mathematical modeling of mass transfer in the soaking of this seed, empirical models were used. A few empirical models predicting a component content (most commonly water) have been applied to soaking (absorption) and desorption processes of several food materials. The Peleg, the Mitscherlich, the Exponential and the Page models are among the most used.

The Peleg model was proposed by Peleg (1988) to predict the water adsorption of soaking of rice and other adsorption operations. It can be written as in Equations 7 and 8:

$$
X_{w}^{n}=X_{w, i}^{n}+\frac{t}{k_{1}+k_{2} t}
$$

where $k_{1}\left(\mathrm{~h} \cdot \%^{-1}\right)$ and $k_{2}\left(\%^{-1}\right)$ are constants. $X_{w}^{n}$ tends to $X_{e}^{n}$, the equilibrium water content, after infinite time:

$$
X_{w, e}^{n}=X_{w, i}^{n}+\frac{1}{k_{2}}
$$

The Mitscherlich model, which has been mostly used in agriculture, was adapted from Wood \& Harden (2006). The form of the model used in this study is presented in Equation 9:

$$
X_{w}^{n}=X_{w, e}^{n}+\left(X_{w, i}^{n}-X_{w, e}^{n}\right) k^{-t}
$$

where $k$ is the kinetic a constant $\left(\%^{t}\right)$.

The exponential model is the most commonly used model to describe mass transfer phenomena (Gekas, 1992). It can be written as in Equation 10:

$$
X_{w}^{n}=X_{w, e}^{n}+\left(X_{w, i}^{n}-X_{w, e}^{n}\right) e^{-k t}
$$

where $k$ is the kinetic constant $\left(\mathrm{h}^{-1}\right)$. This model can be seen as being derived from the convection model, using $k t$ instead of $k^{\prime} A t / V$,where $k^{\prime}$ would be the mass transfer coefficient $(\mathrm{m} / \mathrm{s})$.

The Page model is similar to the Exponential model, but with the time raised to a third constant (da Silva et al., 2012), as presented in Equation 11:

$$
X_{w}^{n}=X_{w, e}^{n}+\left(X_{w, i}^{n}-X_{w, e}^{n}\right) e^{-k_{1} t^{k_{2}}}
$$

where and $k_{1}$ and $k_{2}$ are kinetic constants.

R software (R Core Team, 2017) was used for model fitting. The parameters of the models were estimated by non-linear least squares. Quality of fit was evaluated by the Coefficient of Determination $\left(\mathrm{R}^{2}\right)$ and the Lack of Fit (LoF) test (Montgomery \& Runger, 2007). The LoF test subdivides the residuals in those due to experimental error (estimated from deviation between replicates) and residuals due to the difference between experimental and predicted results. A value of $P$ below 0.05 is an indication that the mathematical model does not describe the experimental data adequately.

\section{Results and discussion}

\subsection{Physical properties and observation of the seed coat- cotyledons interface}

As any other pulse, grass pea contains two cotyledons circumscribed by a seed coat (Wood et al., 2011). The coatcotyledons interface reveals voids between the two parts (Figure 1). These voids are partly responsible for the porosity of the grass pea which was found to be $13.651 \%( \pm 0.546)$. This is almost twice the true porosity of another legume seed, chickpea, determined in another work to be $7.341 \%$ (Costa et al., 2018). The true porosity of grass pea was not found in the literature, while published results for bulk porosity (spaces between grass pea seeds) range from 34.0 to $37.7 \%$ for different varieties and moisture contents (Kenghe et al., 2013). The porosity partly explains the initial water uptake and, if the porous spaces are completely filled with water, can justify more than $9 \%$ of the grass pea weight increase during soaking.

Since size is one of the determining variables in mass transfer, in order to study its effect on soaking grass pea seeds were divided into three different classes according to their size. In an extreme case of diffusion dependent phenomena, the mass transfer time is directly proportional to the square distance to the center of a solid, or if the phenomena is convection, time is inversely proportional to the area per volume ratio for (Gekas, 1992). As already mentioned, for mathematical of mass transfer purposes, grass pea shape cannot be adequately approximated by an ideal shape or characterized by a single dimension or a combination of various dimensions, thus its area per volume ratio was used in this work as a criterion to test the influence of the physical dimension on the mass transfer rate during soaking.

The three groups of seeds were characterized in respect to its mass, water content and area per volume ratio (Table 1). Area per volume $(\mathrm{A} / \mathrm{V})$ is obviously smaller for larger seeds, since for any two solids of the same shape, the larger one has the smallest $\mathrm{A} / \mathrm{V}$ ratio. Water content was determined to be

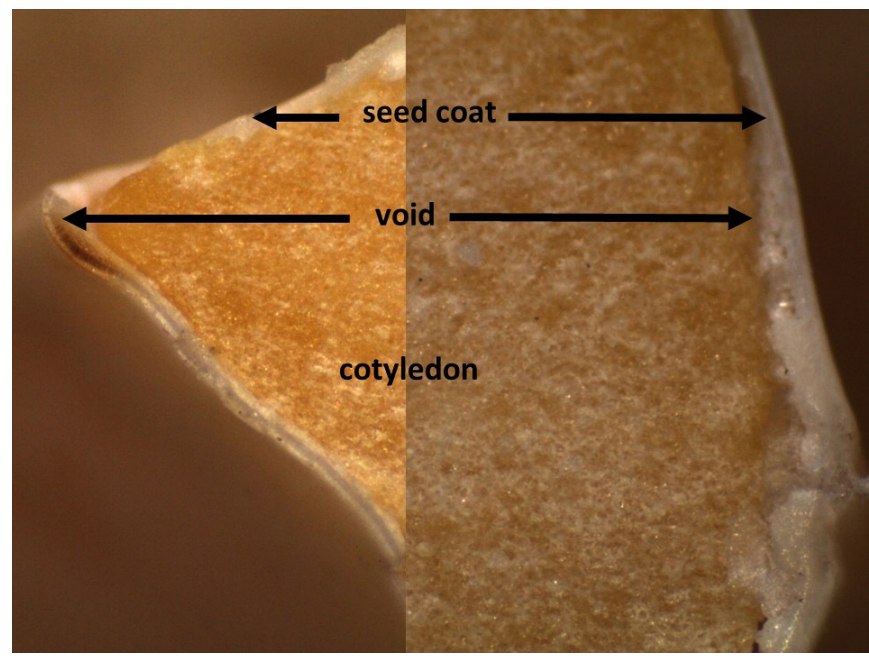

Figure 1. Observation of the Lathyrus sativus seed coat-cotyledons interface with 30x magnification. 
$11.86 \%$ for the smallest seed group and $14.07 \%$ for the largest. Campbell (1997) indicates 7.5-8.2\% as a typical range for this seed. Different initial water contents of the seeds will affect the mass transfer because of the different driving forces at the start of soaking. However, the observed changes of approximately $2 \%$ within these samples will not significantly affect water transfer kinetics.

Water content increases with decreasing seed size (Table 1). These results are in accordance with Kenghe et al. (2013), that observed this proportionality between seed size and water content for a range of equilibrium moisture contents of several grass pea varieties. Greater quantities of water are retained in larger seeds that have a greater distance between the surface and the center, taking longer for the seeds to dry.

\subsection{Water uptake}

\section{Short overview of water uptake mechanisms}

Water uptake in pulses starts as soon as the pulse is immersed in the soaking solution. It starts by being adsorbed at the seed skin, entering through the micropyle (Coffigniez et al., 2019), filling voids under the skin and below it to open spaces. Water then moves to the inner structure of the pulse (Miano et al., 2017), the cotyledons, which are composed of cells walls (fibers) involving a matrix of proteins that accommodate starch granules. Fibers, starch and proteins have a high-water holding capacity, leading to absorption of water as soon as there is contact between them, causing the rearrangement of molecules and swelling. The volume increase does not occur immediately as the mass starts to increase, leading to an increase of the density of pulse at the beginning of soaking, followed by an increase of volume until the end of the operation, as reported for chickpea soaking (Costa et al., 2018). The water uptake rate is higher at the beginning and decreases along the soaking time.

\section{Goodness of fit of the mathematical models}

Experimental water uptake kinetic curves were fitted by the Peleg, Mitscherlich, Exponential and Page models, to find which one better describes the water transfer in the soaking of grass pea. These models were also used to infer about its physical mechanisms and properties.

The four mathematical models were fitted to each set of experimental data of area per volume and temperature, in a total of 12 experimental curves. The coefficient of determination and the probability for not having Lack of Fit are presented in Table 2. The quality of fit was high and similar for all the mathematical models, with a Lack of Fit probability higher than 0.05 for almost all sets, showing a higher experimental error than the deviation due to the model prediction. The coefficient of determination $\left(\mathrm{R}^{2}\right)$ varies from around $0.69-0.70$, for the poorest fit $\left(\mathrm{A} / \mathrm{V}=9.86 \mathrm{~cm}^{-1}\right.$ at $\left.100{ }^{\circ} \mathrm{C}\right)$, to $0.93-0.94$, for the best fit $\left(\mathrm{A} / \mathrm{V}=8.71 \mathrm{~cm}^{-1}\right.$ at $\left.25^{\circ} \mathrm{C}\right)$. The coefficient of determination changes were as large as 0.25 between different datasets, but no more than 0.04 between different models for the same dataset. Thus, it can be easily concluded that the difference in the fitting quality is more likely related to the experimental set being fitted than to the mathematical models.

Note that although an $\mathrm{R}^{2}$ value with an order of magnitude of 0.69 is usually considered a poor coefficient of determination, the dispersion of experimental data in the soaking of grass pea is high, as can be observed in Figure 2, making it impossible to find mathematical models that increase this coefficient, for the respective datasets.

The goodness of fit of the Mitscherlich and Exponential models, given either by the Lack of Fit and the $\mathrm{R}^{2}$, were the same, hence further iterations were only done with the Exponential model because it can be interpreted in terms of physical mechanisms. The Page model, although resulting in slightly higher $\mathrm{R}^{2}$ for some sets, had an additional parameter (total of 3 ) compared to

Table 2. Goodness of fit evaluated by the Lack of Fit test and the Coefficient of Determination.

\begin{tabular}{|c|c|c|c|c|c|c|c|c|}
\hline & \multicolumn{4}{|c|}{ Lack of Fit } & \multicolumn{4}{|c|}{$\mathrm{R}^{2}$} \\
\hline & $25^{\circ} \mathrm{C}$ & $50{ }^{\circ} \mathrm{C}$ & $75^{\circ} \mathrm{C}$ & $100^{\circ} \mathrm{C}$ & $25^{\circ} \mathrm{C}$ & $50^{\circ} \mathrm{C}$ & $75^{\circ} \mathrm{C}$ & $100^{\circ} \mathrm{C}$ \\
\hline \multicolumn{9}{|l|}{$\mathrm{A} / \mathrm{V}=11.47 \mathrm{~cm}^{-1}$} \\
\hline Peleg & 0.38 & 0.66 & 0.49 & 0.36 & 0.78 & 0.90 & 0.88 & 0.70 \\
\hline Exponential & 0.38 & 0.66 & 0.49 & 0.36 & 0.79 & 0.90 & 0.88 & 0.70 \\
\hline Mitscherlich & 0.38 & 0.66 & 0.49 & 0.36 & 0.79 & 0.91 & 0.88 & 0.70 \\
\hline Page & 0.29 & 0.69 & 0.43 & 0.34 & 0.79 & 0.91 & 0.89 & 0.70 \\
\hline \multicolumn{9}{|l|}{$\mathrm{A} / \mathrm{V}=9.86 \mathrm{~cm}^{-1}$} \\
\hline Peleg & 0.41 & 0.35 & 0.34 & 0.37 & 0.70 & 0.88 & 0.93 & 0.69 \\
\hline Exponential & 0.38 & $0.04^{*}$ & 0.70 & 0.42 & 0.70 & 0.86 & 0.93 & 0.69 \\
\hline Mitscherlich & 0.38 & $0.04^{*}$ & 0.70 & 0.42 & 0.70 & 0.86 & 0.93 & 0.69 \\
\hline Page & 0.34 & 0.68 & 0.59 & 0.32 & 0.70 & 0.89 & 0.93 & 0.70 \\
\hline \multicolumn{9}{|l|}{$\mathrm{A} / \mathrm{V}=8.71 \mathrm{~cm}^{-1}$} \\
\hline Peleg & 0.16 & 0.17 & 0.05 & 0.74 & 0.94 & 0.92 & 0.93 & 0.82 \\
\hline Exponential & 0.18 & 0.09 & 0.30 & 0.87 & 0.93 & 0.91 & 0.92 & 0.82 \\
\hline Mitscherlich & 0.18 & 0.09 & 0.30 & 0.87 & 0.93 & 0.91 & 0.92 & 0.82 \\
\hline Page & 0.17 & 0.15 & 0.27 & 0.81 & 0.94 & 0.92 & 0.93 & 0.86 \\
\hline
\end{tabular}

${ }^{*}$ Curve fit presents Lack of Fit $(\mathrm{P}<0.05)$. 

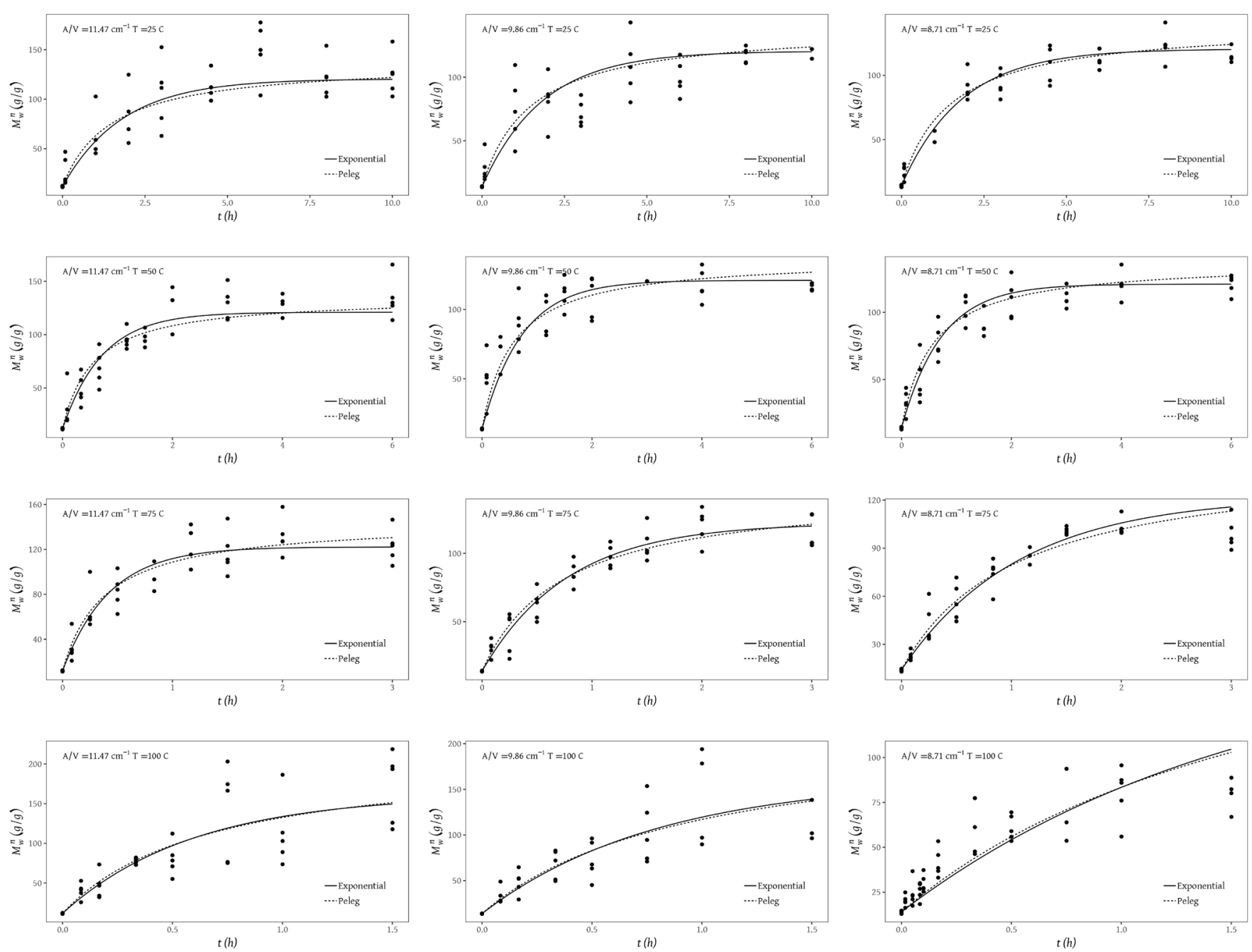

Figure 2. Fitting of the Peleg and Exponential models and experimental normalized mass of water per grass pea $M_{w}^{n}$ during soaking time at $25^{\circ} \mathrm{C}$, $50^{\circ} \mathrm{C}, 75^{\circ} \mathrm{C}$ and $100{ }^{\circ} \mathrm{C}$.

the other models (total of 2) and, for some datasets, resulted on $\mathrm{P}>0.05$ for the significance of the constants (data not shown), an undesirable result due to the excessively high number of parameters. For this reason, this model was not selected for a second iteration. As a consequence, only the results from the Peleg and Exponential models were used for further analysis.

\section{Peleg and exponential models: estimated water content at equilibrium and rate constants}

After the first fitting iteration of the Peleg and Exponential models to all experimental data sets, two more iterations were carried out in order to obtain more robust results from the datasets for $X_{\mathrm{e}}$ and kinetic constants, with the goal of obtaining more meaningful information regarding the kinetic behavior.

The results of the first iteration fit with the Peleg model gave similar values of $k_{2}$ for all the sub-sets of $A / V$ at each temperature. Thus, a second fitting iteration was carried out fitting a single $k_{2}$ for each temperature and a $k_{1}$ for each temperature (data not shown). Since the second iteration revealed similar $k_{1}$ values for all $A / V$ for the temperatures $25^{\circ} \mathrm{C}$ and $50^{\circ} \mathrm{C}$, a third fit was obtained considering a single pair $k_{1}-k_{2}$ for the subset at $25^{\circ} \mathrm{C}$ and another for the subset at $50{ }^{\circ} \mathrm{C}$ (Table 3).

The Peleg constant $k_{1}$ is related to the water uptake rate. A lower $k_{1}$ indicates a faster water uptake. The rate increases from 25 to $50^{\circ} \mathrm{C}$, with $k_{1}$ decreasing from $11.6 \times 10^{-3}$ to $4.54 \times 10^{-3} \mathrm{~h} \cdot \%^{-1}$. This trend was not observed at $75^{\circ} \mathrm{C}$, where an increase of the average $k_{1}$ was observed (at this temperature, the average value for all the different $A / V$ sets was $5.39 \times 10^{-3} \mathrm{~h} \cdot \%^{-1}$ ) for. This may be due to gelatinization that starts occurring when the ratio of starch to water is equal or higher than 0.75 (Delcour \& Hoseney, 2010) at temperatures above $55^{\circ} \mathrm{C}$, as already mentioned. During gelatinization the water is bounded to starch, slowing down diffusion to the center of the pulse. Kon (1979) also observed no rate increase in the soaking of beans between $40{ }^{\circ} \mathrm{C}$ and $90{ }^{\circ} \mathrm{C}$. Finally, when increasing the temperature to $100^{\circ} \mathrm{C}$, a small increase in $k_{1}$ (an average value of $5.87 \times 10^{-3} \mathrm{~h} \cdot \%^{-1}$ ) was again observed. However, this does 
not mean that the water transfer rate decreased. In Figure 2 it is possible to observe that the rate at $100^{\circ} \mathrm{C}$ is much higher at $100^{\circ} \mathrm{C}$ than at $75^{\circ} \mathrm{C}$. The constant $k_{1}$ did not show a big increase because its estimation is highly dependent on the estimation of $k_{2}$. The parameter $k_{2}$ sets the $X_{\mathrm{e}}$ level, while $k_{1}$ sets how fast $X_{\mathrm{e}}$ is achieved. Thus, an estimation of a smaller $k_{2}$ for the same curve will prompt the estimation of a higher value of $k_{1}$.

The values of $k_{1}$ are in the same order of magnitude of those obtained for the soaking of other legumes. Shafaei et al. (2016), Prasad et al. (2010) and Turhan et al. (2002), studying the soaking of chickpea, obtained $k_{1}$ values between $22 \times 10^{-3} \mathrm{~h} \cdot \%^{-1}$ and $0.95 \times 10^{-3} \mathrm{~h} \cdot \%^{-1}$ for temperatures between 20 and $100^{\circ} \mathrm{C}$. For the soaking of cowpeas, Sopade \& Obekpa (1990) obtained values between $3.07 \times 10^{-3}$ and $9.2 \times 10^{-3} \mathrm{~h} \cdot \%^{-1}$ for $2-40^{\circ} \mathrm{C}$, and for soaking of beans, Shafaei et al. (2016) obtained values between $58.5 \times 10^{-3}$ and $1.3 \times 10^{-3} \mathrm{~h} \cdot \%^{-1}$ for temperatures ranging 5 to $45^{\circ} \mathrm{C}$. However, the value of $k$ cannot be compared to the results of other works that studied different materials, because the $k$ implicitly accounts for the effect of size and shape of the solid being soaked. While the grass pea has a parallelepiped type shape, chickpea has an ellipsoid shape (Chenoll et al., 2009) and beans have a cylindrical type shape. Additionally, the distance to center or the ratio of area per volume, both important in limiting mass transfer rates, are not usually published, making it impossible to establish comparisons with this work.

There was no observable effect of the area per volume ratio at 25 and $50^{\circ} \mathrm{C}$, but its effect is notable at 75 and $100^{\circ} \mathrm{C}$. At the higher temperature range, the $k_{1}$ constant presents an inversely proportional dependence on $A / V$. This was expected because a lower area for mass transfer will result in lower mass transfer rates. This implies that the $k_{1}$ constant has somehow included the $A / V$ volume effect, as in a convection type behavior where this term appears in the equation (see comments after Equation 11).

The values of $X_{e}$, estimated from $k_{2}$, were found to increase slightly from $167 \%$ at $25{ }^{\circ} \mathrm{C}$ to $192 \%$ at $75{ }^{\circ} \mathrm{C}$ but increased tremendously to $346 \%$ at $100^{\circ} \mathrm{C}$ (Table 3 ). $X_{e}$ was found to be independent of temperature in legumes in the range $2-40^{\circ} \mathrm{C}$ for soybean, cowpea and peanut (Sopade \& Obekpa, 1990), and for chickpea within the range $25-45^{\circ} \mathrm{C}$ with values ranging from 55 to $60 \%$ (Shafaei et al., 2016). $X_{e}$ was also found to decrease with temperature in several legumes: for chickpea within 20 to $100^{\circ} \mathrm{C}$ by Turhan et al. (2002), decreasing from an order of magnitude of 150 to $110 \%$ (values estimated the authors); and for unblanched red kidney beans between 20 and $60{ }^{\circ} \mathrm{C}$, decreasing from 173 to $103 \%$ (Abu-Ghannam \& McKenna, 1997). The opposite trend was obtained by Shafaei et al. (2016) for $5-45^{\circ} \mathrm{C}$ for 3 varieties of beans, increasing from 93 to $131 \%$, on average, and by Yildirim et al. (2011) that measured an increase of $X_{\mathrm{e}}$ from 120 to $150 \%$, from $20^{\circ} \mathrm{C}$ to $97^{\circ} \mathrm{C}$. These last results are in accordance with the knowledge that the water holding capacity is known to be higher at higher temperatures for starch (Sayar et al., 2003, studying chickpea) and protein (King \& Ashton, 1985, studying soybean). Differences to the expected behavior may be due to pre-treatments such as a previous blanching step (Abu-Ghannam \& McKenna, 1997), and factors such as the age and the variety of the seeds (Paredes-López et al., 1991).

The observations of the results of the Exponential model provide similar results as the Peleg model. As for the Peleg model, three iterations were also carried out with the same overall trends as in the exponential model (Table 3), with similarities being observed between the constant $k_{1}$ of the Peleg model and the constant $k$ of the exponential model, and $X_{\mathrm{e}}$ obtained by both models. The influence of temperature on $X_{\mathrm{e}}$ and on the kinetic constants, and its effect on the different $A / V$ sets, can also be observed on the Exponential model constants. The relevant difference is that the Exponential model predicts lower $X$, from $138 \%$ at $25^{\circ} \mathrm{C}$ to $254 \%$ at $100^{\circ} \mathrm{C}$, closer to the values for other legumes already cited. This can be explained by the hyperbolic trend of the Exponential model being abrupt when compared to the Peleg model. A simple observation of the fittings (Figure 2) illustrates that towards longer soaking times, the Peleg curve points to a higher $X_{\mathrm{e}}$ compared to experimental data of the water content, while the Exponential model tends to a flatter end. The Exponential model thus delivers $X_{\mathrm{e}}$ values closer to experimental water content values obtained at longer times

Table 3. Constants and its standard deviations for the fitting of the Peleg and Exponential models and estimated equilibrium moisture content after the third fitting iteration.

\begin{tabular}{|c|c|c|c|c|c|c|c|c|c|c|c|c|c|c|}
\hline \multirow{2}{*}{$\mathrm{T}\left({ }^{\circ} \mathrm{C}\right)$} & \multirow{2}{*}{$\begin{array}{c}\mathrm{A} / \mathrm{V} \\
\left(\mathrm{cm}^{-1}\right)\end{array}$} & \multicolumn{7}{|c|}{ Peleg model } & \multicolumn{5}{|c|}{ Exponential model } & \multirow{2}{*}{$\frac{\text { Experimental data }}{\mathrm{X}_{\mathrm{w}, \mathrm{e}}{ }^{* *}(\%)}$} \\
\hline & & \multicolumn{2}{|c|}{$k_{1} \times 10^{3}\left(\mathrm{~h} \cdot \%^{-1}\right)$} & \multicolumn{2}{|c|}{$k_{2} \times 10^{3}\left(\%^{-1}\right)$} & $\mathrm{R}^{2}$ & \multicolumn{2}{|c|}{$\mathrm{X}_{\mathrm{w}, \mathrm{e}} *(\%)$} & \multicolumn{2}{|c|}{$\mathrm{k}\left(\mathrm{h}^{-1}\right)$} & \multicolumn{2}{|c|}{$\mathrm{X}_{\mathrm{w}, \mathrm{e}} *(\%)$} & \multirow[t]{2}{*}{$\mathrm{R}^{2}$} & \\
\hline 25 & 11.47 & & & & & & & & & & & & & \\
\hline & 9.86 & 11.6 & $( \pm 1.62)$ & 7.92 & $( \pm 0.34)$ & 0.83 & 167 & $( \pm 6)$ & 0.547 & $( \pm 0.06)$ & 138 & $( \pm 4)$ & 0.81 & $165( \pm 21)$ \\
\hline & 8.71 & & & & & & & & & & & & & \\
\hline \multirow[t]{3}{*}{50} & 11.47 & & & & & & & & & & & & & \\
\hline & 9.86 & 4.54 & $( \pm 0.38)$ & 8.10 & $( \pm 0.22)$ & 0.88 & 168 & $( \pm 4)$ & 1.38 & $( \pm 0.10)$ & 146 & $( \pm 3)$ & 0.88 & $158( \pm 18)$ \\
\hline & 8.71 & & & & & & & & & & & & & \\
\hline \multirow[t]{3}{*}{75} & 11.47 & 2.84 & $( \pm 0.31)$ & & & & & & 2.36 & $( \pm 0.23)$ & & & & \\
\hline & 9.86 & 5.51 & $( \pm 0.48)$ & 7.48 & $( \pm 0.25)$ & 0.91 & 192 & $( \pm 6)$ & 1.29 & $( \pm 0.11)$ & 156 & $( \pm 3)$ & 0.91 & $173( \pm 28)$ \\
\hline & 8.71 & 7.83 & $( \pm 0.64)$ & & & & & & 0.94 & $( \pm 0.08)$ & & & & \\
\hline \multirow[t]{3}{*}{100} & 11.47 & 3.35 & $( \pm 0.57)$ & & & & & & 1.69 & $( \pm 0.36)$ & & & & \\
\hline & 9.86 & 4.77 & $( \pm 0.69)$ & 4.93 & $( \pm 0.64)$ & 0.74 & 346 & $( \pm 43)$ & 1.26 & $( \pm 0.25)$ & 254 & $( \pm 23)$ & 0.73 & $286( \pm 94)$ \\
\hline & 8.71 & 9.50 & $( \pm 1.32)$ & & & & & & 0.63 & $( \pm 0.12)$ & & & & \\
\hline
\end{tabular}

${ }^{\star}$ Estimated with Equation 5 with $X^{n}$ evaluated experimentally at the longest time as $84.6,81.1,76.5$ and $62.4 \%$, respectively at $25{ }^{\circ} \mathrm{C}, 50{ }^{\circ} \mathrm{C}, 75^{\circ} \mathrm{C}$ and $100{ }^{\circ} \mathrm{C}$; ${ }^{\sharp} \mathrm{Based}$ on the water contents of the last soaking time. 



Figure 3. Normalized mass of grass pea $\left(M^{n}\right)$ versus ratio of solids per initial mass of grass pea $X_{s}^{n}$ during soaking at $25^{\circ} \mathrm{C}, 50^{\circ} \mathrm{C}, 75^{\circ} \mathrm{C}$ and $100{ }^{\circ} \mathrm{C}$.

and is thus more adequate than the Peleg model to estimate $X_{\mathrm{e}}$ (Table 3). Nevertheless, both models coincide in the trend of increasing $X_{\mathrm{e}}$ from 50 to $100^{\circ} \mathrm{C}$.

Other authors also observed the influence of the mathematical models on the estimation of $X_{\mathrm{e}}$. Studying the soaking of penne pasta, Cunningham et al. (2007) also obtained different $X_{\mathrm{e}}$ with the Peleg and Weibull models, with estimates differing between $-90 \%$ and $20 \%$, depending on the temperature. The model should thus be chosen carefully if conclusions about the food material properties are to be drawn.

Activation energy between 25 and $50{ }^{\circ} \mathrm{C}$ for the Peleg and Exponential models is the same, of $30 \mathrm{~kJ} / \mathrm{mol}$ (data not shown), lower than the $59.3 \mathrm{~kJ} / \mathrm{mol}$ obtained by (Turhan et al., 2002) for the Peleg model for chickpea within temperatures below gelatinization $\left(<55^{\circ} \mathrm{C}\right)$. The values obtained in this work are also lower for activation energies of diffusivities for temperatures below gelatinization that fit with the range 47.6-49.8 kJ/mol (Sayar et al., 2001; Seyhan-Gürtas et al., 2001). No activation energy was calculated for the range $75-100{ }^{\circ} \mathrm{C}$ due to the already referred dependence of estimation of $k_{1}$ on the other constant of the model.

\subsection{Relation of water transfer with other changes in grass pea}

Water uptake provides the medium for solids loss during soaking of grass pea and part of that loss is of antinutritional factors, including a desirable loss of the neurotoxin $\beta$-ODAP (Hailu et al., 2015). Computed as the difference between the percentage of solids per initial chickpea mass to initial time $\left(X_{s, i}^{n}-X_{s}^{n}\right)$, the obtained values of solids lost from grass pea range from a minimum of approximately $16 \%$ at $25^{\circ} \mathrm{C}$ to a maximum of $44 \%$ at $100^{\circ} \mathrm{C}$ (Figure 3 ). The minimum value was similar to the one reported for the soaking of chickpeas to be slightly more than $20 \%$ in starch during $9 \mathrm{~h}$ of soaking at room temperature (Frias et al., 2000). Kon (1979) observed smaller losses from white beans during soaking at $20^{\circ} \mathrm{C}$, reported to be $4 \%$, and comparable losses at $60^{\circ} \mathrm{C}, 70^{\circ} \mathrm{C}$ and $90^{\circ} \mathrm{C}$, estimated to be $17 \%$, explained by the destruction of cell materials that boost at higher temperatures.

Water gain was higher than solids loss until the last one reaches a reduction of $X_{s}^{n}$ from approximately $90 \%$ (app. Initial content) to $80 \%$, leading to an overall increase of grass pea mass (Figure 3). Below $80 \%$ of solids per initial seed mass, the ratio of solids loss per water gain was higher, particularly at $100{ }^{\circ} \mathrm{C}$ (Figure 3 ). The average maximum weight gain ratio was between 2.0 and 2.6 for the entire temperature and seed size ranges, with an average of 2.2 (data not shown). These ratios are higher than those reported for chickpea by Sayar et al. (2001) and Singh et al. (1991), respectively to be $1.97-1.83$ for $20^{\circ} \mathrm{C}$ to $100{ }^{\circ} \mathrm{C}$, and 2.0 at $80^{\circ} \mathrm{C}$.

\section{Conclusions}

During the soaking of grass pea water enters the grass pea through several paths and mechanisms, into this seed of nonideal shape, what prevents, as an initial approach, a mathematical modeling of water uptake based on mechanistic models. Water uptake was modeled successfully with the Peleg and the Exponential models, with several advantages when compared to the Mitscherlich and Page models. The predicted equilibrium moisture content was found to increase, by both Peleg and 
Exponential models, at temperatures between 50 and $100{ }^{\circ} \mathrm{C}$. The values obtained, when compared to experimental values, were overestimated by the Peleg model, and underestimated by the Exponential model. Both models detected an incremental effect of the area per volume ratio of the seed on the water uptake rate but only at $75^{\circ} \mathrm{C}$ and $100{ }^{\circ} \mathrm{C}$.

Additional relevant knowledge for mechanistic mass transfer modeling of soaking of grass pea was obtained. The true porosity of grass pea is $13.651 \%$, almost twice that of the chickpea, for which large voids between the skin and the cotyledons contribute to, is a measure of open spaces into which water can enter by capillary flow. Water uptake, that provides the medium for solids loss, led to relevant solids loss, from app. 18 to $44 \%$.

\section{Acknowledgements}

The authors wish to thank to Fundação para a Ciência e Tecnologia for its support under UID/AMB/00681/2013.

\section{References}

Abu-Ghannam, N., \& McKenna, B. (1997). Hydration kinetics of red kidney beans (Phaseolus vulgaris L. ). Journal of Food Science, 62(3), 520-523. http://dx.doi.org/10.1111/j.1365-2621.1997.tb04420.x.

Campbell, C. G. (1997). Grass pea, Lathyrus sativus L. (18th ed). Itália: Bioversity International.

Chenoll, C., Betoret, N., \& Fito, P. (2009). Analysis of chickpea (var. "Blanco Lechoso") rehydration. Part I. Physicochemical and texture analysis. Journal of Food Engineering, 95(2), 352-358. http://dx.doi. org/10.1016/j.jfoodeng.2009.05.014.

Coffigniez, F., Briffaz, A., Mestres, C., Akissoé, L., Bohuon, P., \& El Maâtaoui, M. (2019). Impact of soaking process on the microstructure of cowpea seeds in relation to solid losses and water absorption. Food Research International, 119, 268-275. http://dx.doi.org/10.1016/j. foodres.2019.02.010. PMid:30884656.

Costa, R., Fusco, F., \& Gândara, J. F. M. (2018). Mass transfer dynamics in soaking of chickpea. Journal of Food Engineering, 227, 42-50. http://dx.doi.org/10.1016/j.jfoodeng.2018.02.004.

Cunningham, S. E., McMinn, W. A. M., Magee, T. R. A., \& Richardson, P. S. (2007). Modelling water absorption of pasta during soaking. Journal of Food Engineering, 82(4), 600-607. http://dx.doi.org/10.1016/j. jfoodeng.2007.03.018.

da Silva WP, e Silva CMDPS, de Sousa, J. A. R., \& Farias, V. S. O. (2012). Empirical and diffusion models to describe water transport into chickpea (Cicer arietinum L.). International Journal of Food Science \& Technology, 48(2), 267-273. http://dx.doi.org/10.1111/ j.1365-2621.2012.03183.x.

Delcour, J. A., \& Hoseney, R. C. (2010). Principles of cereal science and technology. Minnesota: AACC International. http://dx.doi. org/10.1094/9781891127632.

Doyle, J. J., \& Luckow, M. A. (2003). The rest of the iceberg. Legume diversity and evolution in a phylogenetic context. Plant Physiology, 131(3), 900-910. http://dx.doi.org/10.1104/pp.102.018150. PMid:12644643.

Frias, J., Vidal-Valverde, C., Sotomayor, C., Diaz-Pollan, C., \& Urbano, G. (2000). Influence of processing on available carbohydrate content and antinutritional factors of chickpeas. European Food Research and Technology, 210(5), 340-345. http://dx.doi.org/10.1007/s002170050560.

Gekas, V. (1992). Transport phenomena of foods and biological materials. Routledge: New York.
Hailu, D., Abera, S., \& Teka, T. A. (2015). Effects of processing on nutritional composition and anti-nutritional factors of Grass pea (Lathyrus Sativus L): a review. Food Sci Qual Manag, 36, 61-71.

Kenghe, R. N., Nimkar, P. M., \& Shirkole, S. S. (2013). Moisture dependent physical properties of lathyrus. Journal of Food Science and Technology, 50(5), 856-867. http://dx.doi.org/10.1007/s13197011-0428-7. PMid:24425992.

King, R. D., \& Ashton, S. J. (1985). Effect of seed coat thickness and blanching on the water absorption by soybeans. International Journal of Food Science \& Technology, 20(4), 505-509. http://dx.doi. org/10.1111/j.1365-2621.1985.tb01960.x.

Kon, S. (1979). Effect of soaking temperature on cooking and nutritional quality of beans. Journal of Food Science, 44(5), 1329-1334. http:// dx.doi.org/10.1111/j.1365-2621.1979.tb06432.x.

Miano, A. C., Esteves, P., \& Augusto, D. (2017). The hydration of grains : a critical review from description of phenomena to process improvements. Comprehensive Reviews in Food Science and Food Safety, 17(2), 352-370. http://dx.doi.org/10.1111/1541-4337.12328.

Montgomery, D. C., \& Runger, G. C. (2007). Applied statistics and probability for engineers. Hoboken, NJ: Wiley.

Ngudi, D. D., Kuo, Y. H., van Montagu, M., \& Lambein, F. (2012). Research on motor neuron diseases konzo and neurolathyrism: Trends from 1990 to 2010. PLoS Neglected Tropical Diseases, 6(7), e1759. http://dx.doi.org/10.1371/journal.pntd.0001759. PMid:22860149.

Paredes-López, O., Cárabez-Trejo, A., Palma-Tirado, L., \& ReyesMoreno, C. (1991). Influence of hardening procedure and soaking solution on cooking quality of common beans. Plant Foods for Human Nutrition (Dordrecht, Netherlands), 41(2), 155-164. http:// dx.doi.org/10.1007/BF02194084. PMid:1852727.

Peleg, M. (1988). An empirical model for the description of moisture sorption curves. Journal of Food Science, 53(4), 1216-1217. http:// dx.doi.org/10.1111/j.1365-2621.1988.tb13565.x.

Prasad, K., Vairagar, P. R., \& Bera, M. B. (2010). Temperature dependent hydration kinetics of Cicer arietinum splits. Food Research International, 43(2), 483-488. http://dx.doi.org/10.1016/j.foodres.2009.09.038.

R Core Team (2017). R: A language and environment for statistical computing. Vienna: R Foundation for Statistical Computing. Retrieved https://www.R-project.org/.

Sahin, S., \& Sumnu, S. G. (2006). Physical properties of foods. New York: Springer.

Sayar, S., Turhan, M., \& Gunasekaran, S. (2001). Analysis of chickpea soaking by simultaneous water transfer and water-starch reaction. Journal of Food Engineering, 50(2), 91-98. http://dx.doi.org/10.1016/ S0260-8774(00)00196-5.

Sayar, S., Turhan, M., \& Köksel, H. (2003). Application of unreactedcore model to in situ gelatinization of chickpea starch. Journal of Food Engineering, 60(4), 349-356. http://dx.doi.org/10.1016/S02608774(03)00057-8.

Seyhan-Gürtas, F., Ak, M. M., \& Evranuz, E. Ö. (2001). Water diffusion coefficients of selected legumes grown in Turkey as affected by temperature and variety. Turkey J Agric, 25, 297-304.

Shafaei, S. M., Masoumi, A. A., \& Roshan, H. (2016). Analysis of water absorption of bean and chickpea during soaking using Peleg model. Journal of the Saudi Society of Agricultural Sciences, 15(2), 135-144. http://dx.doi.org/10.1016/j.jssas.2014.08.003.

Singh, U., Subrahmanyam, N., \& Kumar, J. (1991). Cooking quality and nutritional attributes of some nely developed cultivars of chickpea (Cicer arietinum). Journal of the Science of Food and Agriculture, 55(1), 37-46. http://dx.doi.org/10.1002/jsfa.2740550106. 
Sopade, P. A., \& Obekpa, J. A. (1990). Modelling Water Absorption in Soybean, Cowpea and Peanuts at Three Temperatures Using Peleg's Equation. Journal of Food Science, 55(4), 1084-1087. http://dx.doi. org/10.1111/j.1365-2621.1990.tb01604.x.

Turhan, M., \& Sagol, S. (2004). Abrupt changes in the rates of processes occurring during hydrothermal treatment of whole starchy foods around the gelatinization temperature - A review of the literature. Journal of Food Engineering, 62(4), 365-371.http://dx.doi.org/10.1016/S0260-8774(03)00252-8.

Turhan, M., Sayar, S., \& Gunasekaran, S. (2002). Application of Peleg model to study water absorption in chickpea during soaking. Journal of Food Engineering, 53(2), 153-159.http://dx.doi.org/10.1016/S0260-8774(01)00152-2.

Urga, K., Fufa, H., Biratu, E., \& Gebretsadik, M. (2006). Effects of blanching and soaking on some physical characteristics of grass pea (Lathyrus sativus). African J Food, 6(1), 1-17. http://dx.doi.org/10.4314/ajfand.v6i1.19174.

Wood, J. A., \& Harden, S. (2006). A method to estimate the hydration and swelling properties of chickpeas (Cicer arietinum L.). Journal of Food Science, 71(4), E190-E195. http://dx.doi.org/10.1111/j.17503841.2006.00009.x.

Wood, J. A., Knights, E. J., \& Choct, M. (2011). Morphology of Chickpea Seeds (Cicer Arietinum L.): Comparison of Desi and Kabuli Types. International Journal of Plant Sciences, 172(5), 632-643. http://dx.doi. org/10.1086/659456.

Yadav, S. S., \& Bejiga, G. (2006). Lathyrus sativus L. In M. Brink \& G. Belay (Ed.), PROTA (Plant Resources of Tropical Africa / Ressources végétales de l'Afrique tropicale). Wageningen, Netherlands: PROTA4U. Retrieved from http://www.prota4u.org/search.asp

Yerra, S., Putta, S., \& Kilari, E. K. (2015). Detoxification of ODAP in Lathyrus sativus by various food processing techniques. Pharmaceutical and Biological Evaluations, 2, 152-159.

Yildirim, A., Öner, M. D., \& Bayram, M. (2011). Fitting Fick's model to analyze water diffusion into chickpeas during soaking with ultrasound treatment. Journal of Food Engineering, 104(1), 134-142. http://dx.doi.org/10.1016/j.jfoodeng.2010.12.005. 


\section{Nomenclature}

$\mathrm{k}$ - constant of the mathematical models

$M$ - mass at time $\mathrm{t}(\mathrm{g})$

$M^{n}$ - normalized mass at time $\mathrm{t}(\mathrm{g} / \mathrm{g})$

$\mathrm{r}$ - radius of the chickpea $(\mathrm{mm})$

$\mathrm{t}$ - soaking time (s)

$\mathrm{T}$ - soaking temperature $\left({ }^{\circ} \mathrm{C}\right)$

$V$ - volume at time $\mathrm{t}\left(\mathrm{cm}^{3}\right)$

$V^{n}$ - normalized volume at time $\mathrm{t}(\mathrm{g} / \mathrm{g})$

$X^{n}$ - water or solid ratio per initial mass of grass pea $(\mathrm{g} / 100 \mathrm{~g})$

$X_{e}$ - water content at equilibrium $(\mathrm{g} / 100 \mathrm{~g} \mathrm{db})$

$\rho$ - density $\left(\mathrm{g} / \mathrm{cm}^{3}\right)$

Subscripts

1,2 - subscripts of constants of the mathematical models

e - equilibrium

$\mathrm{i}$ - at the initial time

$s$ - solids

w - water 